TITLE:

\title{
Taxonomic Relationships of Two Species of Rhacophorus from Vietnam (Amphibia, Rhacophoridae)
}

\author{
AUTHOR(S):
}

MATSUI, MASAFUMI

\section{CITATION:}

MATSUI, MASAFUMI. Taxonomic Relationships of Two Species of Rhacophorus from Vietnam (Amphibia, Rhacophoridae). Current Herpetology 2005, 24(2): 91-93

\section{ISSUE DATE:}

2005-12

URL:

http://hdl.handle.net/2433/216878

\section{RIGHT:}

(C) 2005 by The Herpetological Society of Japan 


\title{
Taxonomic Relationships of Two Species of Rhacophorus from Vietnam (Amphibia, Rhacophoridae)
}

\author{
Author(s): MASAFUMI MATSUI
}

Source: Current Herpetology, 24(2):91-93.

Published By: The Herpetological Society of Japan

DOI: http://dx.doi.org/10.3105/1345-5834(2005)24[91:TROTSO]2.0.CO;2

URL: http://www.bioone.org/doi/

full/10.3105/1345-5834\%282005\%2924\%5B91\%3ATROTSO $\% 5$ D2.0.CO\%3B2

BioOne (www.bioone.org) is a nonprofit, online aggregation of core research in the biological, ecological, and environmental sciences. BioOne provides a sustainable online platform for over 170 journals and books published by nonprofit societies, associations, museums, institutions, and presses.

Your use of this PDF, the BioOne Web site, and all posted and associated content indicates your acceptance of BioOne's Terms of Use, available at www.bioone.org/page/terms_of_use.

Usage of BioOne content is strictly limited to personal, educational, and non-commercial use. Commercial inquiries or rights and permissions requests should be directed to the individual publisher as copyright holder. 


\section{Taxonomic Relationships of Two Species of Rhacophorus from Vietnam (Amphibia, Rhacophoridae)}

\author{
MASAFUMI MATSUI \\ Graduate School of Human and \\ Environmental Studies, Kyoto University, \\ Sakyo, Kyoto 606-8501, JAPAN
}

\begin{abstract}
Rhacophorus notater Smith, 1924, described from a single juvenile, is regarded as conspecific with $R$. annamensis Smith, 1924. Both species were described from the same locality in Vietnam. Although the name $R$. notater appears before $R$. annamensis in the same publication, $R$. annamensis is more popular in name among herpetologists, and its biological details are better clarified than those of $R$. notater. Thus, I propose to treat $R$. notater as a junior synonym of $R$. annamensis.
\end{abstract}

Key words: Ontogenetic color change; Rhacophorus annamensis; Rhacophorus notater; Synonymy; Taxonomy; Vietnam

Rhacophorus annamensis was described from Daban (alt. $200 \mathrm{~m}$ ), Phan Rang Province, S. Annam (=Vietnam) by Smith (1924). The species was once regarded as a subspecies of $R$. pardalis (Wolf, 1936; Bourret, 1942). Rhacophorus annamensis, however, is morphologically quite distinct from $R$. pardalis Günther, 1859, and is now considered a good species (Inger, 1954; Inger et al., 1999). Smith (1924) also described another, more enigmatic rhacophorid, $R$. notater, from the same locality as R. annamensis (Daban, alt. $200 \mathrm{~m}$ ) in the same publication.

My examination of the type of $R$. notater Smith, 1924, deposited in the Natural History Museum, London (BM 1947.2.8.83=1924.1. 31.3, originally M. Smith 2797), confirmed that the individual is just metamorphosed with

Tel: +81-75-753-6846; Fax: +81-753-281;

E-mail address: fumi@zoo.zool.kyoto-u.ac.jp the trace of a tail stub. The specimen has a snout-vent length (SVL) of $19.0 \mathrm{~mm}$, a tibia length of $10.6 \mathrm{~mm}$, and a head width of $6.7 \mathrm{~mm}$. The body is pale gray brown with discrete dark brown blotches on the back (Fig. 1).

A photograph of a juvenile $R$. annamensis just after metamorphosis (Abb. 6 of Ryboltovsky, 1999: 12) clearly shows that the young of this species have a body color quite different from that of adults. Ryboltovsky (1999) described the ground color of the body as bright gray or whitish, with large black spots. This peculiar color pattern is quite similar to that of $R$. notater. Indeed Wolf (1936) suspected that $R$. notater was a young $R$. annamensis.

Ryboltovsky (1999) reported the size at metamorphosis of reared individuals to range from 12 to $14 \mathrm{~mm}$ in SVL, and this size range is smaller than the size of $R$. notater. However, the size at metamorphosis varies greatly in anurans according to the conditions the tadpoles have experienced. In contrast, the body color varies less evidently than the body size (my unpublished data).

Recently, Orlov et al. (2002: 96) noted close similarity of body color between $R$. notater and young $R$. annamensis, and listed only $R$. annamensis in their checklist of Vietnamese amphibians, omitting $R$. notater.

I fully agree with Orlov et al. (2002) in that the two species are very similar, and further consider them to be conspecific. Although Smith (1924) described $R$. notater on page 227 before $R$. annamensis on page 229 of the same paper (Proc. Zool. Soc. London, 1924), $R$. annamensis is more popular in name and its biological details are better established (e.g., Inger et al., 1999) than those of $R$. notater. Therefore, I herewith formally propose to relegate $R$. notater in the synonymy of $R$. annamensis.

\section{ACKNOWLEDGMENTS}

I thank C. McCarthy and B. T. Clarke of The Natural History Museum, London, for allowing me to examine specimens under their 




FIG. 1. Rhacophorus notater. Dorsal (top left), ventral (top right) and lateral (bottom) views of the holotype.

care, and T. Hikida, H. Ota, N. Ananjeva and N. Orlov for providing literature. This study was supported by a grant under The Monbusho International Scientific Research Program (Field Research, No. 10041166).

\section{LITERATURE CITED}

BOURRET, R. 1942. Les Batraciens de l'Indochine. Mem. Inst. Océanogr. l'Indochine, Hanoi 6: x, 1547, 4 pls.

INGER, R. F. 1954. Systematics and zoogeography 
of Philippine Amphibia. Fieldiana: Zool. 33: 181-531,

INGER, R. F., N. ORLOV, AND I. DAREVSKY. 1999. Frogs of Vietnam: A report on new collections. Fieldiana: Zool. N. S. (92): 1-46.

Orlov, N. L., R. W. MurPhy, N. B. ANANJEVA, S. A. RYABOY, AND T.-C. Ho. 2002. Herpetofauna of Vietnam, a checklist. Part I. Amphibia. Russ. J. Herpetol. 9: 81-104.

RYBOLTOVSKY, E. 1999. Bemerkungen zur nachzucht des Flugfrosches Rhacophorus annamen- sis. Elaphe 4: 9-12.

SMITH, M. A. 1924. New tree-frogs from IndoChina and the Malay Peninsula. Proc. Zool. Soc. London 1924: 225-234, 3 pls.

WOLF, S. 1936. Revision der untergattung Rhacophorus (Ausschliesslich der MadagaskarFormen). Bull. Raffles Mus. 12: 137-217.

Accepted: 16 November 2005 